\title{
Developing Bus Rapid Transit
}

Writing on geographical development, James Sidaway (2012:49) asks "how useful is it to talk about the geography of development or of developing countries"? It is a topic that has been discussed at length by academics and practitioners in the field of development studies, yet reverberations seem not to have penetrated certain areas of transport studies despite links between transport, social mobility, poverty alleviation and international development (Hickman 2014, Hickman et al. 2015, World Bank 2002). This commentary is concerned with geographies of development conveyed in literature on bus rapid transit (BRT), a bus-based mode of urban transit that has been championed by academics such as Gilbert (2008) and Venter et al. (2007), and organisations such as the World Bank $(2002,2004)$ as a promising investment in poverty-oriented urban development strategies.

In a recent review of academic and grey BRT literature (Schwanen and Ferbrache 2017), a third of the sources were found to recreate a dichotomous geography of development by employing the terms 'developed' or 'developing'. Prompted by Sidaway's question above, this commentary draws upon critical thought from development studies to consider potential consequences of using 'developed-developing', and possible alternatives that reflect more nuanced and networked approaches than binary and value-laden categories. In doing so, the commentary hopes to prompt a more critical employment of 'developeddeveloping' by transport scholars and practitioners, and to stimulate thoughts towards greater cross-disciplinary dialogue, principally between (BRT) transport and development fields.

\section{'Developed-developing'}

The dichotomous terminology 'developed-developing' has been employed in literature on BRT to distinguish and compare BRT infrastructures, operations and services based upon the socioeconomic status of the countries or cities in which they are found (Cain et al. 2007; Hensher and Golob 2008; Hidalgo and Gutierrez 2013; Mejía-Dugand et al. 2013; Muñoz and Hidalgo 2013; Muñoz and Paget-Seekins 2016). In a review of 180 BRT publications (based on Schwanen and Ferbrache 2017), one third of sources employed 'developed' and/or 'developing' to make generalisations about countries and/or cities. Of those 60 publications, 47 were peer-reviewed academic papers and 13 were non-academic BRT reports. In 16 of the academic papers, authors presented the literature using such terminology, while 15 employed the dichotomy to describe the context of the case being researched. Another 15 also employed 'developed-developing' in terms of lessons learnt and the wider applicability of their findings i.e. in terms of what cities can learn from one another.

More specifically, phrases such as "In the case of developing cities..." (Paget-Seekins and Muñoz 2016:1), "...studies focusing on developed country cities..." (Stokenberga 2014:280) and "Implementation in developed countries has been..." (Higaldo and Gutierrez 2013:10) demonstrate the use of 'developed-developing' as a heuristic device to make broad statements. Maeso-González and Pérez-Cerón (2014) provide an example of analysis differentiated between two types of BRT in developed world regions: North America, 
Oceania and Europe, on the one hand, and in developing regions: South America, Asia and Africa, on the other. While 'developing-developed' may be employed like this as a heuristic device to simplify and classify the world, uncritical use of 'developed-developing' can be ambiguous and misleading and has potential negative consequences, three of which are identified below.

First, 'developed-developing' (re)constructs a bi-modal geography of countries or cities at polar extremes. This overlooks different levels of development between and within countries with BRT. Hodder (2005), Sidaway (2006) and the World Bank (2016) identify 'developed-developing' as an outdated classification in the wake of more nuanced socioeconomic classifications such as NICS, BRICS, CIVETS and MINTs ${ }^{1}$, as well as various tiger (and tiger cub) economies (Sidaway 2012). While BRT literature includes case studies from this range of countries including Curitiba, Brazil (BRIC) (Smith and Raemaekers 1998); Bogotá and Cali, Colombia (CIVETS) (Delmelle and Casas 2012, Estupiñán and Rodríguez 2008, Jaramillo et al. 2012); Istanbul, Turkey (CIVETS and MINTs) (Babalik-Sutcliffe and Cengiz 2015); Lagos, Nigeria (MINTS) (Cervero and Dai 2014); and Seoul, South Korea (Tiger) (Cervero and Kang 2011), such studies continue to employ the broader term 'developing', thus placing such cities under one 'catch-all' category.

Second, 'developing-developed' is employed in this way at different scales of analysis. As above quotations indicate, 'developed-developing' sometimes refers to a city, at other times to a country, and sometimes to all cities within a particular territory e.g. "...developed country cities..." (Stokenberga 2014:280). Precisely which cities and countries are included or excluded is often unapparent, leading to ambiguity across and between these different scales.

Third, Murphy (2013:140) argues that 'developed-developing' is "value-laden terminology" that implies a further dichotomy of wealthy-poor (countries and people), and a hegemonic relationship between poor and unempowered developing countries in need of support and development assistance from wealthy and empowered countries (Schech 2014). BRT has been identified by Cervero (2013) and Venter et al. (2017) as a 'pro-poor' form of transport with important mobility benefits to lower-income communities in lower-income cities including Bogotá and Cali; Istanbul; Ahmedabad and Delhi (India); Johannesburg (South Africa); Lima (Peru) and Mexico City (Mexico). Jaramillo et al. (2012) and Venter et al. (2017) demonstrate how BRT can help to improve mobility for poor people though rather than distinguish one category of 'poor', these authors acknowledge different strata and explain how BRT infrastructure often remains concentrated among higher strata of those considered 'poor' (see Farmer (2011) for similar evaluation of BRT services in Los Angeles and Chicago, United States). Acknowledgement of the nuances within and between binary categories such as these help to provide more critical insight to understand the impacts and potential of BRT among urban/transport planners, policy-makers, decision-makers and academics.

\footnotetext{
${ }^{1}$ NICs (Newly industrialised countries); BRICs (Brazil, Russia, India, China); CIVETS (Colombia, Indonesia, Vietnam, Eygpt, Turkey, South Africa); MINTs (Mexico, Indonesia, Nigeria, Turkey).
} 
Despite these claims, much BRT research is undertaken within transport planning (and other fields) rather than transport geography, and often needs to generalise to some extent to help with planning BRT infrastructure. In certain cases, 'developing-developed' may provide useful and practical simple classification and cannot be avoided. However, if we follow further arguments from development studies and dispense with 'developed-developing' altogether, what alternative models could be used and with what implications for advancing geographical fields?

\section{Moving on}

In 2016, the World Bank proposed to cease using 'developed-developing' to distinguish between countries (World Bank 2016). While this decision grew from some of the critiques identified above, many development scholars expressed a preference for an alternative geographical terminology: Global North-Global South (North-South), which emerged in the 1980s with publication of the Brandt Report (Brandt Commission 1980, Dirlik 2007). On the one hand the dichotomous 'North-South' faces similar weaknesses as some of those expressed above (as well as actual global positioning of some countries outside their associated zones, such as Australia, and the middling status of a city such as Istanbul spanning two continents ${ }^{2}$ ), on the other hand, Murphy (2013:140) notes "growing ascendence of a Global North-Global South discourse" in place of 'developed-developing' (see also Dirlik 2007).

The emergence of 'North-South' in the 1980s coincides with early BRT publications, however it is only more recent literature such as Paget-Seekins (2015) and Wood (2015b) that engages critically with these terms, simultaneously complementing recent development literature. Mawdsley (2017:1), a development geographer, observes disruption of a "normalised hierarchy" of support and assistance from northern countries to southern countries, with a rise in South-South relations in the 21st century. Similar patterns are identified by Paget-Seekins (2015:119), who argues that "BRT is a technology transfer between countries in the Global South", and Wood (2015b) who acknowledges the 'SouthSouth' (South African - South American) geography of connections underlying BRT policy and decision-making. This critical engagement with broad geographical narratives provides a shared focus and potential for cross-disciplinary engagement: BRT examples may provide valuable empirical material for development studies, while BRT scholars may gain further conceptual insight to advance a more critical approach around the language of international development. Hickman (2014) suggests that transport has not yet been fully taken up by development geographers and BRT may offer a useful lens towards more integrated working across such fields.

An alternative way to develop BRT research is to expand empirical analysis that is city or corridor specific, as promoted by Muñoz and Hidalgo (2013), and Paget-Seekins and Muñoz (2016). Research focused on specific city contexts can help to shift analysis from top-down to bottom-up perspectives as has been examined by development geographers to focus on

\footnotetext{
${ }^{2}$ BRT in Istanbul plays an important role as the main mode of public transit across the Istanbul Strait connecting the European and Asian parts of the city (Alpkokin and Ergun 2012).
} 
the specificities of "different historical trajectories, economic and demographic profiles, regional and international agendas and relations" (Mawdsley 2014:633). While the aim of bottom-up research is to move away from contextualising BRT in terms of 'developingdeveloped', how can one continue analysing connections between cities that may learn from one another? (McFarlane 2006). Wood's (2014, 2015a, 2015b) analysis of connections, networks and relations between cities through a BRT network is a useful example. Borrowing from Mobile Urbanism and policy mobility theories (McCann and Ward 2011, 2012), Wood traces actual connections between South African cities with BRT (Johannesburg and Cape Town) and South American cities, particularly BRT in Bogotá but also in Guayaquil, Ecuador; Pereira, Colombia; Buenos Aires, Argentina; and Santiago, Chile, to show how BRT was planned and implemented in South Africa. In contrast, had she analysed from a broad top-down approach by comparing South African cities to those of similar development standing, she would have made comparisons with Indian cities such as Ahmedabad, and cities in other African countries such as Lagos (2015b). By following actual trajectories, Wood's analysis is richer and provides a more informed insight to processes in and through specific places.

This commentary has problematised unconscious and uncritical deployment of 'developeddeveloping' in BRT literature. Sometimes misleading and often ambiguous, this is not to say that we can or should try to avoid using these terms. As heuristic devices, they provide a generalised distinction to focus on differences and, broadly speaking, the terms are recognised (if disputed) across the globe. However, the issue is that the usefulness of the terminology is paled by overgeneralisation that overlooks between and within country distinctions, mutual inclusion and exclusion of cities (and countries), as well as value-laden terminology of associated 'wealthy-poor'. While a more critical engagement with binary terminologies is called for, this commentary suggested alternative models that borrow from and speak to contemporary discussions within development studies and strands of urban studies. These models unsettle top-down approaches to focus instead on tracing mobile connections, relations and networks as they emerge from grounded examples, and connect or disconnect places across the boundaries of epistemological classifications such as 'developed-developing'. In this way, BRT can better speak to processes and debates (SouthSouth relations, policy mobility, mobile urbanism) that are current within other fields of geography and broader disciplines, and potentially contribute to cross-disciplinary work.

Alpkokin, P. and Ergun, M. 2012. Istanbul Metrobus: first intercontinental bus rapid transit Journal of Transport Geography 24:58-66

Babalik-Sutcliffe, E. and Can Cengiz, E. 2015. Bus rapid transit system in Istanbul: a success story or flawed planning decision? Transport Reviews 35:792-813

Brandt Commission, 1980. North-South: A Program for Survival: Report of the Independent Commission on International Development Issues. Cambridge, MA: MIT Press

Cain, A., Darido, G., Baltes, M.R., Rodriguez, P. and Barrios, J.C. 2007. Applicability of TransMilenio bus rapid transit system of Bogotá, Colombia, to the United States.

Transportation Research Record 2034:45-54 
Cervero, R. 2013. Bus rapid transit (BRT): an efficient and competitive mode of public transport. Working Paper 2013-01. Berkeley, CA: Institute of Urban and Regional Development

Cervero, R. and Dai, D. 2014. BRT TOD: Leveraging transit oriented development with bus rapid transit investments. Transport Policy 36: 127-138

Cervero, R. and Kang, C.D. 2011. Bus rapid transit impacts on land uses and land values in Seoul, Korea. Transport Policy 18: 102-116

Delmelle, E.C. and Casas, I. 2012. Evaluating the spatial equity of bus rapid transit-based accessibility patterns in a developing country. The case of Cali, Colombia. Transport Policy 20:36-46

Dirlik A (2007) Global south: Predicament and promise. The Global South 1(1\&2):12-23.

Estupiñán, N. and Rodríguez, D.A. 2008. The relationship between urban form and station boardings for Bogota's BRT. Transportation Research Part A 42:296-306

Farmer, S., 2011. Uneven public transportation development in neoliberalizing Chicago, USA. Environment and Planning A 43:1154-1172.

Gilbert, A. 2008. Bus rapid transit: is Transmilenio a miracle cure? Transport Reviews 28:439467

Hensher, D., and Golob, T. 2008. Bus rapid transit systems: A comparative assessment. Transportation 35, 501-518

Hidalgo, D. and Gutierrez, L. 2013. BRT and BHLS around the world: explosive growth, large positive impacts and many issues outstanding. Research in Transportation Economics 39:813

Hickman, R. 2014. Transport and sustainability: development pathways. In Desai, V. and Potter, R.B. (eds). The Companion to Development Studies. Third edition. London: Routledge. pp.378-383.

Hickman, R. Givoni, M. Bonilla, D. and Banister, D. (eds) 2015. Handbook of Transport and Development. Cheltenham: Edward Elgar

Hodder, R. 2005. Development Geography. London: Routledge

Jaramillo, C. Lizárraga, C. and Grindlay, A.L. 2012. Spatial disparity in transport social needs and public transport provision in Santiago de Cali (Colombia). Journal of Transport Geography 24:340-357

Maeso-González, E. and Pérez-Cerón, P. 2014. State of the art of bus rapid transit transportation. European Transport Research Review 6:149-156

Mawdsley, E. 2014. Human rights and South-South development cooperation: reflections on the 'rising powers' as international development actors. Human Rights Quarterly 36(3):630652

Mawdsley, E. 2017. Development geography I: cooperation, competition and convergence between 'North' and 'South'. Progress in Human Geography. 41(1):108-117

McCann, E. and Ward, K. (eds) 2011. Mobile Urbanism: Cities and Policymaking in the Global Age. Minneapolis, MN: Minnesota University Press

McCann, E. and Ward, K. 2012. Assembling urbanism: following politics and 'studying through' the sites and situations of policy making. Environment and Planning A 44:42-51

McFarlane, C. 2006. Crossing borders: Development, learning and the North-South divide. Third World Quarterly 27: 1413-1437 
Mejía-Dugand, S., Hjelm, O., Baas, L. and Ríos, R.A. 2013. Lessons from the spread of bus rapid transit in Latin America. Journal of Cleaner Production 50:82-90

Muñoz, J.C. and Hidalgo, D. 2013. Workshop 2: bus rapid transit as part of enhanced service provision. Research in Transportation Economics 39:104-107

Muñoz, J.C. and Paget-Seekins. 2016. Restructuring Public Transport Through Bus Rapid transit: An International and Interdisciplinary Perspective. Bristol: Policy Press

Murphy, A.B. 2013. Advancing geographical understanding: why engaging grand regional narratives matters. Dialogues in Human Geograph 3(2):131-149

Paget-Seekins, L. 2015. Bus rapid transit as a neoliberal contradiction. Journal of Transport Geography 48:115-120

Paget-Seekins, L. and Muñoz, J.C. 2016. The promise of BRT. In Muñoz, J.C. and PagetSeekins. (eds). Restructuring Public Transport Through Bus Rapid transit: An International and Interdisciplinary Perspective. Bristol: Policy Press. pp.1-13

Schech, S. 2014. Culture and development. In Desai, V. and Potter, R.B. (eds). The Companion to Development Studies. Third edition. London: Routledge. pp.42-46.

Schwanen, T. and Ferbrache, F. 2017 Bibliography of Research on Bus Rapid Transit TSU Working Paper Series, Ref. 1068. School of Geography and the Environment, Oxford.

Sidaway, J.D. 2012. Geographies of development: new maps, new visions, The Professional Geographer 64(1):49-62

Smith, H. and Raemaekers. 1998. Land use patterns and transport in Curitiba. Land Use Policy 15(3):233-251

Stokenberga, A. 2014. Does bus rapid transit influence urban land development and property values: a review of the literature. Transport reviews 34(3):276-296

Venter, C.G., Jennings, D., Hidalgo and A.F.V. Pineda (2017) 'The equity impacts of bus rapid transit: a review of the evidence, and implications for sustainable transport' International Journal of Sustainable Transportation. Available at:

http://www.tandfonline.com/doi/full/10.1080/15568318.2017.1340528

Wood, A. 2014. Moving policy: global and local characters circulating bus rapid transit through South African cities. Urban Geography 35(8):1238-1254

Wood, A. 2015a. Multiple temporalities of policy circulation: gradual, repetitive and delayed processes of BRT adoption in South African Cities. International Journal of Urban and Regional Research 39(3):568-580

Wood, A. 2015b. The politics of policy circulation: unpacking the relationship between South African and South American cities in the adoption of bus rapid transit. Antipode 47(4):10621079

World Bank, 2002. Cities on the Move: World Bank Urban Transport Strategy Review. Washington, DC: World Bank

World Bank, 2004. Project Information Document (PID). Appraisal stage. Report no. AB784.

World Bank, 2016. Word Development Indicators. Washington, DC: World Bank 